\title{
IMPROVING THE UTILIZATION OF CASSAVA ROOT MEAL IN LAYING HEN DIETS
}

\author{
A.A. Ghazalah and M.O. Abd-Elsame \\ Animal Production Department, Faculty of Agriculture, Cairo University, Egypt.
}

\section{SUMMARY}

\begin{abstract}
total number of 200 Lohman Selected Leghorn (LSL) laying hens 25 weeks of age were used to study the effect of using different levels of cassava root meal (CRM) on laying hen performance, egg quality, nutrients digestibility and economical efficiency. In this study, 0, 25 or $50 \%$ of CRM were used in isocaloric $(2850 \mathrm{ME} \mathrm{kcal} / \mathrm{kg}$ ) and isonitrogenous (17\%) diets. Each level of CRM (25 or $50 \%$ ) was supplemented with 0.0 or $0.20 \%$ of sodium thiosulfate (STS) as an attempt to improve the utilization of CRM in laying hen diets. Hens were kept in cages of wire floored batteries under similar conditions of management for 12 weeks experimental period. Water and feed (in mash form) were offered ad-libitum during the experimental period with 16 hours light/day regimen. The overall results showed that laying hen performance and nutrient digestibility values were decreased gradually with increasing dietary CRM level. While, adding sodium thiosulfate to dietary CRM improved the average values of both laying hen performance and nutrients digestibility comparing to those fed dietary CRM without supplementation. Data showed that there were no significant differences in the average values of egg quality (as shape index, shell thickness, Hugh units, egg total lipids and egg cholesterol) due to dietary CRM levels. However, adding $0.20 \%$ of sodium thiosulfate to dietary CRM improved the average values of economical efficiency. In conclusion, CRM could be used in laying hen diets up to $50 \%$ with addition of $0.2 \%$ sodium thiosulfate to improve laying hen performance and economical efficiency.
\end{abstract}

Keywords: Laying hen, cassava root meal, sodium thiosulfate, egg production.

\section{INTRODUCTION}

Poultry production has been affected by high cost of feeds, especially of conventional energy and protein feed ingredients. Cereal grains mainly yellow corn is the conventional energy source in poultry diets which constitute over $50 \%$ of the diet for the different classes of poultry (Lyayi, 2009). While, the rapid growth of human population has intensified the competition between human and livestock for cereals, resulting to high cost of the cereal grains and consequently high prices of poultry products. Therefore, it is necessary to look for an alternative and cheaper sources of feed ingredients which can replace for yellow corn to reduce the cost of poultry production. Cassava, Tapioca or Yucca ( Manihot esculenta ) are examples of those sources which can be used in poultry diets. The world cassava production was 288 million tons in 2016 (which distributed as follows: 157, 99 and 32 million tones in Africa, Asia and Latin America, respectively), which represents a steady increase in production over previous years. Furthermore, the world price for cassava root was $51 \$ /$ ton, while the world price for corn was $153 \$$ ton $(F A O, 2016)$. The average values of metabolizable energy (ME) for cassava root meal (CRM) were varied from 3140 to $3470 \mathrm{kcal} / \mathrm{kg}$ (Agwunobi and Okeke, 2000). Moreover, Oladunjoye et al. (2010); Anaeto and Adighibe (2011); Oyewumi (2013); Yin et al. (2014) and Diarra and Devi (2015) demonstrated that, yellow corn could be replaced with CRM up to 50\% in laying hen diets without detrimental effect on laying hen performance, egg quality and economical efficiency. On the other hand, the presence of hydrocyanic acid (HCN) in cassava tuber $(23-42 \mathrm{ppm})$ is responsible for retardation of digestion and growth rate of poultry (Stephen, 2003; Udedibie et al., 2004 and Chauynarong et al., 2009). Therefore, the detoxification of cassava meal HCN to make it suitable for poultry feeding has been reported by Yeong and Syed (1978) who found that CRM could be used in laying hen diets up to $60 \%$ with supplemented methionine, sodium sulfate or sodium thiosulfate as a source of sulfur ion. Also, Enriquez and Ross (1972) and Grodh et al. (1989) showed that $40-60 \%$ of maize has been satisfactorily replaced by CRM without adverse effects on egg production when they supplemented CRM diets with $0.30 \%$ methionine. Similarly, Ghazalah et al. (2009) obtained that supplementation of methionine to CRM diets improved laying hen performance and economical efficiency of egg production. 
Therefore, the present study was planned to improve the utilization of cassava root meal in laying hen diets by using sodium thiosulfate as a source of ionic sulfur.

\section{MATERIALS AND METHODS}

The present work was conducted in the Agricultural Experimental Station, Faculty of Agriculture, Cairo University. A total number of 200 Lohman Selected Leghorn (LSL) laying hens 25 weeks of age were used in this study to explain the effect of using different levels of cassava root meal (CRM) with supplementation of sodium thiosulfate (STS) on laying hen performance, egg quality, nutrients digestibility and economical efficiency of egg production. Hens were kept in previously cleaned and fumigated cages of wire floored batteries in an open system house under similar conditions of management. Laying hens were randomly distributed into 5 groups, each containing 40 birds in 4 replicates. Each of the 5 groups were given one of the following 5 isocaloric $(2850 \mathrm{ME} \mathrm{kcal} / \mathrm{kg})$ and isonitrogenous $(17 \%)$ diets for 12 weeks experimental period. The $1^{\text {st }}$ diet was formulated mainly from yellow corn as an energy source and served as the control. In the other 4 diets, CRM was used at levels of 25 or $50 \%$ of the diet. Each level of CRM was used without supplementation or supplemented with $0.20 \%$ of sodium thiosulfate (STS) as an attempt to improve the utilization of CRM in laying hen diets. The determined chemical composition of CRM used in this experiment was: 11.5, 4.5, 0.7, 7.5, 5.2 and $70.6 \%$ for moisture, CP, EE, CF, ash and NFE, respectively. Therefore, ME was $3230 \mathrm{kcal} / \mathrm{kg}$ as calculated by the following equation:

$\mathrm{ME}=53+38(\mathrm{CP}+2.25 \mathrm{EE}+1.1 \mathrm{NFE})$ according to Scott et al. (1976). The experimental diets and their chemical composition are presented in Table (1). Water and feed (in mash form) were offered $a d$ libitum allover the experimental period with 16 hours light/ day regimen. Twenty eggs were taken randomly from each treatment every four weeks for testing their quality. At the end of the feeding trial, 20 hens, 4 of each treatment (one from each replicate) were randomly chosen and individually housed in metabolic cages to determine the nutrients digestibility and nitrogen balance of the experimental diets. The analyses of feed and dried excreta were done according to the official methods (AOAC, 1990). The data obtained were statistically analyzed by using MSTAT-C (1989) procedure with Oneway analysis. Duncan's multiple range test was used to detect any significant differences among the experimental means (Duncan, 1955).

The experimental model used was:

Where:

$$
Y i j=\mu+T i+e i j
$$

Yij = an observation

$\mu=$ the overall mean

$\mathrm{Ti}=$ Effect of treatments, $\mathrm{i}$ (1 to 5)

eij= Experimental error.

Finally, all treatments were economically evaluated by calculating the net revenue per unit of total feed cost.

\section{RESULTS AND DISCUSSION}

\section{Laying hen performance:}

The effect of dietary treatments on laying hen performance is listed in Table (2). Results show that the average values of egg production were decreased gradually with increasing dietary CRM up to $50 \%$. The reduction in egg production values by increasing dietary CRM level may be due to the increase of hydrocyanic acid (HCN) content in the diet as well as the low protein quality of such diets. However, the addition of sodium thiosulfate at level of $0.20 \%$ of the diet as a source of sulfur ions improved egg production. These results are confirmed by Yeong and Syed (1978) who indicated that in the presence of methionine or sodium thiosulfate as a source of sulfur ion, the HCN is transformed in the liver by the rhodanese enzyme to non-harmful form as thiocyanate (HSCN), which is excreted in 
the urine. Also, Ghazalah et al. (2009) found that adding methionine as a source of ionic sulfur to dietary CRM may be required to improve the quality and utilization of dietary protein.

Results in Table (2) showed that egg weight values were decreased gradually with increasing CRM levels up to $50 \%$ of the diet. This may be due to the low level of fat content in CRM. While, the addition of sodium thiosulfate to dietary CRM improved egg weight values only at $25 \%$ level, but still lower than the control. This suggests that sulfur ion has a direct role in egg formation. In this connection, Ghazalah et al. (2009); Anaeto and Adighibe (2011) and Oyewumi (2013) found that egg weight decreased significantly when laying hens were fed diets containing CRM more than 50\% as substitution of yellow corn.

Results in Table (2) show that there was a tendency towards decreased feed intake as the level of CRM increased in the diet. The reduction in feed intake with increasing dietary CRM level was due to the un palatability of CRM for its powdery nature (Vantsawa, 2009). However, the addition of sodium thiosulfate improved feed intake values of diets containing CRM. These results are confirmed by Ghazalah et al. (2009) who showed that feed intake values decreased gradually with increasing dietary CRM up to $75 \%$ as substitution of yellow corn. While, Yin et al. (2014) found that there were no significant differences in feed intake values due to feeding laying hens on diets containing 50\% CRM as replacement for maize.

Data in Table (2) show that there was an improvement in FCR values with adding sodium thiosulfate to laying hen diets which containing different levels of CRM. This may be due to the improve in both egg production and egg weight with using sodium thiosulfate as a source of ionic sulfur. These results are in agreement with those obtained by Ghazalah et al. (2009) who found that the addition of methionine as a source of ionic sulfur to dietary CRM improved the FCR values.

\section{Egg quality:}

The effect of experimental treatments on egg quality is shown in Table (3). Results obtained show that the average values of shape index, shell thickness $(\mathrm{mm})$ and Hugh units did not differ significantly by increasing dietary CRM levels up to $50 \%$. These results are in harmony with Oladunjoye et al. (2010) and Oyewumi (2013) who indicated that there were no significant differences in shell thickness values due to replacing 50\% of maize with CRM in laying hen diets. Data in Table (3) show that the average values of egg total lipids and egg cholesterol (as percentage of albumin and yolk mixture) were almost constant for all treatments and there were no significant differences among treatments due to using different levels of dietary CRM. In this connection, Yin et al. (2014) found that egg yolk cholesterol did not differ significantly with feeding laying hen on diets containing 50\% CRM. On the contrary, Oladunjoye et al. (2010) showed that egg total lipids and egg cholesterol were decreased significantly with feeding laying hen on diets containing 50\% CRM.

\section{Nutrients digestibility:}

The average values of nutrients digestibility and nitrogen balance of different experimental diets were estimated as percentage and shown in Table (4). In general, the average values of both nitrogen balance (NB) and the digestion coefficient for organic matter (OM), crude protein (CP) and ether extract (EE) were decreased with increasing dietary CRM level. However, feeding laying hens on diets containing CRM and supplemented with STS improved the average values of nitrogen balance and nutrients digestibility. This due to that adding ionic sulfur may be required to improve the quality and utilization of dietary protein. These results are in a good harmony with those obtained by Hamza (2007) who found that nutrients digestibility were decreased significantly with increasing CRM levels in broiler diets up to 75\% substitution of yellow corn. Also, Ghazalah et al. (2009) showed significant differences in the average values of nutrients digestibility and nitrogen balance which were decreased due to feeding laying hens on dietary CRM comparing to control diet.

\section{Economical efficiency:}

Data presented in Table (5) show the economical efficiency and money return per hen at the end of experimental period as affected by different dietary treatments. Generally, egg production and feeding cost are the most important factors which involved in the achievement of maximum efficiency of egg production. The economical efficiency values were calculated according to the prevailing market (selling) price of egg, which was $0.90 \mathrm{LE}$ on average during the experimental period. In that, feeding laying hens on diets containing 25 or $50 \%$ CRM with supplementation of sodium thiosulfate at level of $0.2 \%$ improved both net revenue, economical efficiency and relative economical efficiency values compared to control diet. These results coincided with those obtained by Salami (2000); Vantsawa 
(2009) and Ghazalah et al. (2009) who found that parboiled CRM at $50 \%$ replacement of maize in layer diets resulted in optimum production with good economic returns.

On the basis of results obtained, it could be concluded that cassava root meal could be used in laying hen diets up to $50 \%$ with supplementation of sodium thiosulfate at level of $0.2 \%$ as a source of ionic sulfur to improve laying hen performance, nutrients digestibility and economical efficiency of egg production.

\section{REFERENCES}

Agwunobi, L.N.and Okeke, J. E. (2000). Metabolisable energy of some improved cassava cultivars for broiler chicken. African. J. of Root and Tuber Crops, 4: 35.

Anaeto, M. and Adighibe, L.C. (2011). Cassava root meal as substitute for maize in layers ration. Brazilian J. Poult. Sci., 13: 153-156.

AOAC (1990). Association of Official Agricultural Chemists. Official Methods of Analysis, $15^{\text {th }}$ ED., Washington, D. C.

Chauynarong, N; Elangovan, A. V. and Iji, P. A. (2009). The potential of cassava products in diets for poultry. World's Poult. Sci., 65: 23-35.

CLFF, Central Lab for Food \& Feed. Technical Bulletin Nr. 1 ( 2001). Feed composition tables for animal and poultry feedstuffs used in Egypt.

Diarra,S.S and Devi, A. (2015). Feeding value of some cassava by-products meal for poultry: A review. Pakistan J. Nutr., 14(10): 735-741.

Duncan, D. B (1955). Multiple range and multiple F tests. Biometrics, 11: 1-24.

Enriquez, F. Q and Ross, E. (1972). Cassava root meal in grower and layer diets. Poult. Sci., 51: 497.

FAO (2016). Food and Agricultural Organization of the United Nations Statistics (FAO STAT Data base results) Production year book, FAO Rome.

Ghazalah, A. A.; Soliman, A. Z. M and Abd-Elsame, M. O. (2009). Effect of cassava root meal and methionine levels on laying hens performance. Egyptian J. Nutrition and Feeds, 12 (3) Special Issue : 697- 705.

Grodh, C. V; C. V. Reddy and V. R. Reddy (1989). Utilization of tapioca (Manihot esculenta crantz) for egg production. Indian J. of Poult. Sci., 24: 287.

Hamza, S. S. M (2007). Using cassava plant (Manihot esculenta) in diet for broiler chick performance in Egypt and Nigeria. M. SC. Thesis. Institute of African Research and Studies, Cairo University.

Iyayi, E.A.(2009). Prospects and challenges of unconventional poultry feedstuffs. Proceedings of the $3^{\text {rd }}$ Nigerian International Poultry Summit, Abeokuta, Ogun State Nigeria, 22-26 February, 2009.

MSTAT-C. (1989). Software program for the design and analysis of agronomic research experiments. Michigan St. Univ.,M.S., U.S.A.

Oladunjoye, I.O.; Ojebiyi, O and Amao, O. A. (2010). Effect of feeding processed cassava peel meal based diet on the performance characteristics, egg quality and blood profile of laying chicken. Agricultura Tropicaet Subtropica. 43 (2) : 119-126.

Oyewumi, S. O. (2013). Performance, egg quality and haematological characteristics of layers fed cassava grit meal. Transnational J. Sci. Tech., 3(8): 50-57.

Salami, R. I (2000). Preliminary studies on the use of parboiled cassava peel meal as a substitute for maize in layers diets. Tropical Agric., 77: 199.

Scott, M. L.; Nesheim, M. C and Young, R. J. (1976). Nutrition of the chicken. $2^{\text {nd }}$ Ed. Scott and Associates Publishers Ithaca, New York.

Stephen, S. (2003). Biochemical evaluation of cassava flour meal in broiler diets. MS Tech thesis. Federal University of Technology Minna, Niger State, Nigeria.

Udedibie, A. B. I; Anyaegbu, B. C.; Onyechekwa, G. C. and Engbuokporo, O. R. (2004). Effect of feeding level of fermented and unfermented cassava tuber meals on performance of broilers. Nigeria. J. Anim. Prod., 31: 211.

Vantsawa, P. A (2009). Utilization of low-grade cassava meal (gari) in the diets of egg type chicks (0-8 weeks). Pakistan J. of Nutr., 8: 39. 
Yeong, S. W and Syed, A. B. (1978). Effects of sulphates and methionine supplementation in high cassava based diets for layers. Mardi. Res. Bull., 6(2): 202-207.

Yin, Y. K.; Hidemi, T.; Win, M. H.; Sarayut, T.; Yoshimi, I and Yasuhiro, K. (2014). Effects of cassava substitute for maize based diets on performance characteristics and egg quality of laying hens. Int. J. Poult. Sci., 13 (9) : 518-524.

\section{تحسين الاستفادة من مسحوق درنات الكسافا في علائق الاجاج البياض عبدالله على غزاله و ممدوح عمر عبدالسمبع \\ قسم الإنتاج الحيوانسي ـ كلية الزراعة - جامعة القاهرة - الجبيزة - مصر.}

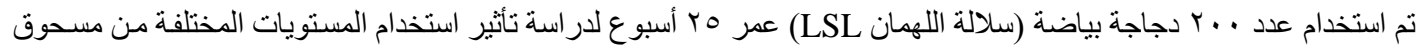

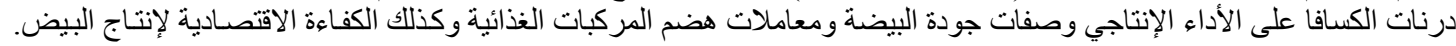

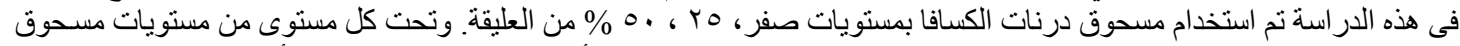

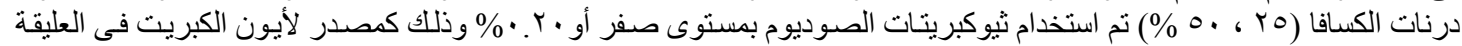

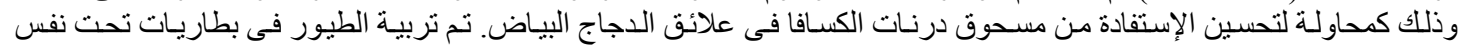

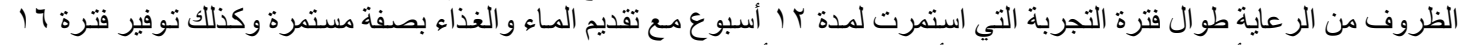

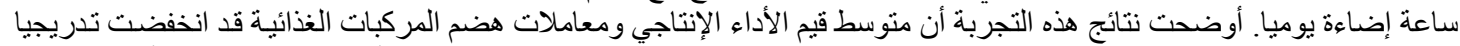

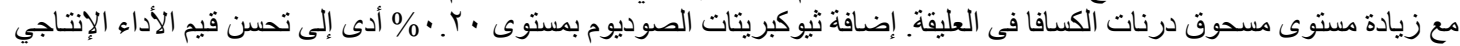

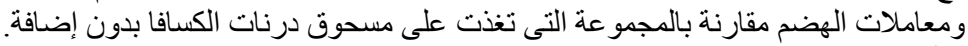

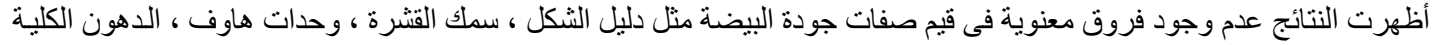

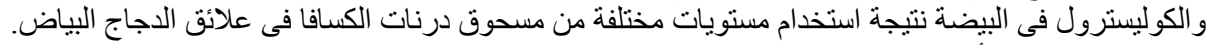

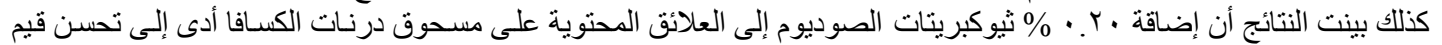

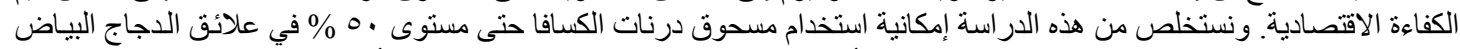

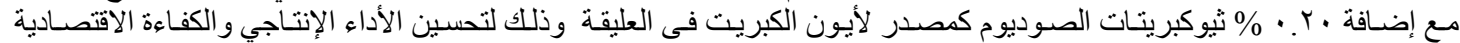
لإنتاج البيض. 
Table (1): Composition and calculated analysis of the experimental diets.

\begin{tabular}{|c|c|c|c|c|c|}
\hline \multirow[b]{3}{*}{ Ingredients } & \multicolumn{5}{|c|}{ CRM \% } \\
\hline & \multirow{2}{*}{$\begin{array}{c}0 \\
\text { Control } \\
\text { (T1) }\end{array}$} & \multicolumn{2}{|c|}{25} & \multicolumn{2}{|c|}{50} \\
\hline & & $\begin{array}{c}0 \% \text { STS } \\
\text { (T2) }\end{array}$ & $\begin{array}{c}0.2 \% \text { STS } \\
\text { (T3) }\end{array}$ & $\begin{array}{c}0 \% \text { STS } \\
\text { (T4) }\end{array}$ & $\begin{array}{c}0.2 \% \text { STS } \\
\text { (T5) }\end{array}$ \\
\hline Yellow corn & 60.0 & 35.0 & 35.0 & 10.0 & 10.0 \\
\hline Cassava root meal & - & 25.0 & 25.0 & 50.0 & 50.0 \\
\hline Soybean meal (44\%) & 13.0 & 13.0 & 13.0 & 12.0 & 12.0 \\
\hline Corn gluten meal $(60 \%)$ & 9.0 & 11.0 & 11.0 & 14.0 & 14.0 \\
\hline Wheat bran & 4.60 & 2.90 & 2.90 & 1.30 & 1.30 \\
\hline Vegetable oil & 1.80 & 1.50 & 1.50 & 1.10 & 1.10 \\
\hline Di-Ca Phosphate & 2.0 & 2.0 & 2.0 & 2.0 & 2.0 \\
\hline Limestone & 8.60 & 8.60 & 8.40 & 8.60 & 8.40 \\
\hline $\mathrm{NaCl}$ & 0.40 & 0.40 & 0.40 & 0.40 & 0.40 \\
\hline Vit. \& Min. Premix * & 0.30 & 0.30 & 0.30 & 0.30 & 0.30 \\
\hline L-lysine $\mathrm{HCl}$ & 0.30 & 0.30 & 0.30 & 0.30 & 0.30 \\
\hline DL-methionine & - & - & - & - & - \\
\hline Sod. Thiosulfate (STS) & - & - & 0.20 & - & 0.20 \\
\hline Total & 100.0 & 100.0 & 100.0 & 100.0 & 100.0 \\
\hline \multicolumn{6}{|l|}{ Calculated analysis $* *$} \\
\hline $\mathrm{CP} \%$ & 17.0 & 17.0 & 17.0 & 17.0 & 17.0 \\
\hline $\mathrm{ME} \mathrm{cal} / \mathrm{kg}$ & 2850 & 2850 & 2850 & 2850 & 2850 \\
\hline $\mathrm{Ca} \%$ & 3.70 & 3.70 & 3.70 & 3.70 & 3.70 \\
\hline Avi. P \% & 0.48 & 0.48 & 0.48 & 0.48 & 0.48 \\
\hline $\mathrm{EE} \%$ & 4.50 & 3.60 & 3.60 & 2.50 & 2.50 \\
\hline $\mathrm{CF} \%$ & 3.10 & 4.20 & 4.20 & 5.20 & 5.20 \\
\hline Lys. \% & 0.90 & 0.90 & 0.90 & 0.90 & 0.90 \\
\hline Meth. \% & 0.40 & 0.40 & 0.40 & 0.40 & 0.40 \\
\hline Price/ Ton (LE) & 5350 & 5020 & 5080 & 4720 & 4780 \\
\hline
\end{tabular}

Table (2): Effect of dietary treatments on laying hen performance.

\begin{tabular}{ccccccc}
\hline \multicolumn{3}{c}{ Treatments } & & & & Parameters \\
NO. & CRM & STS & EP $(\%)$ & EW $(\mathrm{g})$ & FI $(\mathrm{g})$ & $\begin{array}{c}\text { FCR } \\
(\mathrm{g} \text { feed/g egg })\end{array}$ \\
\hline 1 & - & - & $82.8^{\mathrm{a}}$ & $61.6^{\mathrm{a}}$ & $103.7^{\mathrm{a}}$ & $2.03^{\mathrm{c}}$ \\
2 & 25 & - & $72.5^{\mathrm{b}}$ & $56.5^{\mathrm{c}}$ & $98.9^{\mathrm{b}}$ & $2.41^{\mathrm{b}}$ \\
3 & 25 & 0.20 & $81.5^{\mathrm{a}}$ & $58.7^{\mathrm{b}}$ & $99.5^{\mathrm{b}}$ & $2.08^{\mathrm{c}}$ \\
4 & 50 & - & $64.3^{\mathrm{c}}$ & $56.3^{\mathrm{c}}$ & $94.3^{\mathrm{c}}$ & $2.60^{\mathrm{a}}$ \\
5 & 50 & 0.20 & $71.2^{\mathrm{b}}$ & $56.8^{\mathrm{c}}$ & $95.8^{\mathrm{c}}$ & $2.37^{\mathrm{b}}$ \\
& LSD & & 1.70 & 1.20 & 1.50 & 0.07 \\
\hline
\end{tabular}

$a, b$ and $c:$ Means in each column bearing the same superscripts are not significantly different $(P<0.05)$. 
Table (3): Effect of dietary treatments on egg quality.

\begin{tabular}{cccccccc}
\hline \multicolumn{3}{c}{ Treatments } & \multicolumn{7}{c}{ Parameters } \\
\hline NO. & CRM & STS & $\begin{array}{c}\text { Shape } \\
\text { index }\end{array}$ & $\begin{array}{c}\text { Shell Thick. } \\
(\mathrm{mm})\end{array}$ & H. U & $\begin{array}{c}\text { Egg total } \\
\text { lipids }(\%)\end{array}$ & $\begin{array}{c}\text { Egg } \\
\text { cholest. } \\
(\mathrm{mg} / \mathrm{g})\end{array}$ \\
\hline 1 & - & - & 75.3 & 35.5 & 85.2 & 10.2 & 5.1 \\
2 & 25 & - & 74.4 & 34.8 & 84.8 & 10.3 & 5.8 \\
3 & 25 & 0.20 & 75.2 & 34.7 & 84.2 & 10.4 & 5.2 \\
4 & 50 & - & 74.8 & 34.4 & 85.1 & 10.5 & 5.3 \\
5 & 50 & 0.20 & 74.5 & 34.2 & 84.3 & 10.6 & 5.4 \\
& LSD & & 2.50 & 2.10 & 1.50 & 1.30 & 1.20 \\
\hline
\end{tabular}

Table (4): Effect of dietary treatments on nutrients digestibility and nitrogen balance (\%).

\begin{tabular}{ccccccccc}
\hline \multicolumn{7}{c}{ Treatments } & \multicolumn{7}{c}{ Parameters } \\
\hline NO. & CRM & STS & OM & CP & EE & CF & NFE & NB \\
1 & - & - & $83.9^{\mathrm{a}}$ & $85.1^{\mathrm{a}}$ & $74.5^{\mathrm{a}}$ & 24.5 & 85.5 & $73.1^{\mathrm{a}}$ \\
2 & 25 & - & $79.1^{\mathrm{b}}$ & $79.8^{\mathrm{b}}$ & $70.9^{\mathrm{c}}$ & 24.7 & 84.7 & $67.8^{\mathrm{b}}$ \\
3 & 25 & 0.20 & $82.5^{\mathrm{a}}$ & $84.2^{\mathrm{a}}$ & $73.5^{\mathrm{ab}}$ & 24.6 & 84.8 & $72.2^{\mathrm{a}}$ \\
4 & 50 & - & $75.2^{\mathrm{c}}$ & $76.8^{\mathrm{c}}$ & $70.3^{\mathrm{c}}$ & 24.3 & 85.9 & $64.8^{\mathrm{c}}$ \\
5 & 50 & 0.20 & $77.8^{\mathrm{b}}$ & $81.3^{\mathrm{b}}$ & $72.7^{\mathrm{b}}$ & 24.5 & 84.7 & $69.3^{\mathrm{b}}$ \\
& LSD & & 1.40 & 1.50 & 1.20 & 1.30 & 1.60 & 1.50 \\
\hline
\end{tabular}

$a, b$ and $c$ :Means in each column bearing the same superscripts are not significantly different $(P<0.05)$.

Table (5): Effect of dietary treatments on economical efficiency.

\begin{tabular}{|c|c|c|c|c|c|c|c|c|c|}
\hline \multicolumn{3}{|c|}{ Treatments } & \multirow{2}{*}{$\begin{array}{l}\text { FI / } \\
\text { hen } \\
(\mathrm{kg})\end{array}$} & \multirow{2}{*}{$\begin{array}{l}\text { Fed cost / } \\
\text { hen (LE) }\end{array}$} & \multirow{2}{*}{$\begin{array}{l}\text { Egg } \\
\text { No./ } \\
\text { hen }\end{array}$} & \multirow{2}{*}{$\begin{array}{c}\text { Total } \\
\text { revenue } \\
(\mathrm{LE})^{\mathrm{a}}\end{array}$} & \multirow{2}{*}{$\begin{array}{c}\text { Net } \\
\text { revenue } \\
(\mathrm{LE})^{\mathrm{b}}\end{array}$} & \multirow{2}{*}{ E. $E^{c}$} & \multirow{2}{*}{$\begin{array}{c}\text { RE.E }{ }^{\mathrm{d}} \\
(\%)\end{array}$} \\
\hline NO. & CRM & STS & & & & & & & \\
\hline 1 & - & - & 8.71 & 46.6 & 70 & 63.0 & 16.4 & 0.35 & 100 \\
\hline 2 & 25 & - & 8.31 & 41.7 & 61 & 54.9 & 13.2 & 0.32 & 91 \\
\hline 3 & 25 & 0.20 & 8.36 & 42.5 & 68 & 61.2 & 18.7 & 0.44 & 126 \\
\hline 4 & 50 & - & 7.92 & 37.4 & 54 & 48.6 & 11.2 & 0.29 & 83 \\
\hline 5 & 50 & 0.20 & 8.05 & 38.5 & 60 & 54.0 & 15.5 & 0.40 & 114 \\
\hline
\end{tabular}

a) Assuming that the selling price of one egg is $0.90 \mathrm{LE}$.

b) Total revenue - feed cost.

c) Net revenue per unit feed cost.

d) Assuming that the E.E of the control diet $=100$. 